\title{
The Integrin $\alpha_{v} \beta_{5}$ Is Expressed on Avian Osteoclast Precursors and Regulated by Retinoic Acid
}

\author{
KAREN SAGO ${ }^{1}$, STEVEN L. TEITELBAUM ${ }^{1}$, KRISTY VENSTROM ${ }^{2}$, LOUIS F. REICHARDT ${ }^{2}$, \\ and F. PATRICK ROSS ${ }^{1}$ \\ ${ }^{1}$ Department of Pathology, Washington University School of Medicine, St. Louis, Missouri, U.S.A \\ 2 Howard Hughes Medical Institute, University of California at San Francisco, San Francisco, \\ California, U.S.A
}

\section{Abstract}

Osteoclasts arise by proliferation, differentiation, and subsequent fusion of marrow-derived precursors, all processes requiring attachment to matrix. Integrins are important mediators of cellmatrix recognition and bone is rich in proteins containing the Arg-Gly-Asp motif, recognized primarily by $\alpha_{v}$ integrins. Thus, we determined if avian osteoclast precursors express integrins capable of mediating initial attachment to matrix proteins. Early, marrow-derived osteoclast precursors, when first isolated, contain no detectable $\alpha_{v} \beta_{3}$, but express an $\alpha_{\mathrm{v}}$ integrin with an $80 \mathrm{kDa}$ associated $\beta$ subunit. Immunoprecipitation with an antibody raised against the conserved $\beta_{5}$ cytoplasmic tail sequence indicates the the $\alpha_{\mathrm{v}}$ associated the integrin is $\alpha_{\mathrm{v}} \beta_{5}$. Retinoic acid is a resorptive steroid, and its exposure to early osteoclast precursors prompts a time- and dose-dependent decrease in $\alpha_{v} \beta_{5}$ expression, while simultaneously stimulating $\alpha_{\mathrm{v}} \beta_{3}$ expression. Northern analysis reveals that retinoic acid decreases $\beta_{5}$ steady- state mRNA, nontranscriptionally, without altering that of $\alpha_{\mathrm{v}}$. The finding $\alpha_{\mathrm{v}} \beta_{5}$ expression decreases under the influence of retinoic acid, an osteoclastogenic steroid, while those of $\alpha_{\mathrm{v}} \beta_{3}$ rise, suggests that these closely related integrins play separate and complementary roles during osteoclast differentiation.

\section{INTRODUCTION}

The Osteoclast is a multinucleated bone-resorbing cell generated by fusion of mononuclear precursors, which are members of the monocyte/macrophage family.(1,2) These precursors arise from hematopoietic stem cells which differentiate under the influence of various cytokines and steroid hormones. $(1,3,4)$ We have shown, in an avian osteo-clast-generating system,(5) that surface expression of the functional osteoclast integrin $\alpha_{v} \beta_{3}$ is regulated by 1,25 dihydroxyvitamin $\mathrm{D}_{3}\left(1,25(\mathrm{OH})_{2} \mathrm{D}_{3}\right),(6-8)$ a hormone stimulating maturation of osteoclast precursors. $(4,9)$ Induction of the integrin by the steroid involves transactivation of both the $\alpha_{v}(8)$ and $\beta_{3}(7)$ genes, thereby precluding determination of which subunit is rate limiting for $\alpha_{\mathrm{v}} \beta_{3}$ expression.

Like $1,25(\mathrm{OH})_{2} \mathrm{D}_{3}$, retinoic acid, another member of the steroid superfamily,(10) stimulates bone resorption in vivo(11) and in vitro. $(3,4,12,13)$ Furthermore, the retinoid and secosteroid share similarity in their mode of action. Thus, they bind to specific receptors, the vitamin D receptor and retinoic acid receptor, respectively, forming heterodimers with the retinoid $\mathrm{X}$ receptor (RXR).(14-16) The heterodimers, once bound to DNA sequences in the regulatory

Address reprint requests to: F. Patrick Ross, Ph.D., Department of Pathology, Washington University School of Medicine, Barnes-Jewish Hospital North, 216 South Kingshighway, St. Louis, MO 63110 U.S.A. 
regions of target genes, act as transcriptional regulators. $(15,16)$ Based on this information, we postulated that retinoic acid may also increase $\alpha_{\mathrm{v}} \beta_{3}$, and find this to be the case. Moreover, the retinoid, like the vitamin $D$ metabolite, transactivates the avian $\beta_{3}$ gene, but, in contrast to 1,25 $(\mathrm{OH})_{2} \mathrm{D}_{3}$, does so without altering $\alpha_{\mathrm{v}}$ transcription, indicating that at least in the case of retinoic acid, $\alpha_{\mathrm{v}} \beta_{3}$ expression is regulated by the $\beta$ subunit.

The integrin $\alpha_{\mathrm{v}} \beta_{5}$, like $\alpha_{\mathrm{v}} \beta_{3}$, recognizes the Arg-Gly-Asp (RGD) amino acid motif.(17,18) Furthermore, human monocytes, cells ontogenetically related to osteoclast precursors, express $\alpha_{v} \beta_{5}$ and $\alpha_{v} \beta_{3}$ in a manner regulated by hematopoietic cytokines. $(19,20)$ Because of the capacity of both $\alpha_{\mathrm{v}}$ integrins to ligand bone matrix proteins such as osteopontin,(18) we asked if avian osteoclast precursors also express the heterodimers $\alpha_{\mathrm{v}} \beta_{3}$ and $\alpha_{\mathrm{v}} \beta_{5}$ and, if so, whether expression of $\alpha_{\mathrm{v}} \beta_{5}$ is regulated by $1,25(\mathrm{OH})_{2} \mathrm{D}_{3}$ and retinoic acid. We report here that freshly isolated avian osteoclast precursors contain $\alpha_{\mathrm{v}} \beta_{5}$, but not $\alpha_{\mathrm{v}} \beta_{3}$, and that retinoic acid decreases expression of the heterodimer by altering steady-state mRNA levels of the $\beta_{5}$ but not the $\alpha_{\mathrm{v}}$ subunit. In contrast, $1,25(\mathrm{OH})_{2} \mathrm{D}_{3}$, a hormone that increases surface expression of $\alpha_{\mathrm{v}} \beta_{3}$, fails to alter either $\beta_{5}$ mRNA or expression of the $\alpha_{v} \beta_{5}$ complex. Most importantly, the fact that $\alpha_{\mathrm{v}} \beta_{5}$ is present in freshly isolated precursors at a time when $\alpha_{\mathrm{v}} \beta_{3}$ is not suggests that $\alpha_{\mathrm{v}} \beta_{5}$ may play a role in matrix recognition by the early precursor cells.

\section{MATERIALS AND METHODS}

\section{Cell isolation and culture}

Avian osteoclast precursors were isolated and cultured as described previously.(5,7) Briefly, bone marrow cells from laying hens maintained on a calcium-free diet for 2-3 weeks were fractionated on Ficoll-Hypaque (Sigma, St. Louis, MO, U.S.A.), and the mononuclear fraction was cultured overnight on Falcon (Lincoln Park, NJ, U.S.A.) plastic cell culture dishes. The nonadherent cells were reisolated and cultured for varying periods of time at $4-6 \times 10^{6}$ cells/ $\mathrm{ml}$ in alpha modified essential medium $/ 5 \%$ fetal bovine serum $+5 \%$ chicken serum, with the addition of $10^{-5}$ to $10^{-8} \mathrm{M}$ all-trans retinoic acid in ethanol (at a final concentration of $<0.1 \%$ ). In specific experiments, cells from the same bird were treated with either $10^{-6} \mathrm{M}$ all-trans retinoic acid or $10^{-8} \mathrm{M} 1,25(\mathrm{OH})_{2} \mathrm{D}_{3}$ for 3 days. All sera used for culture had been charcoalstripped to remove endogenous steroids.

\section{Surface labeling and immunoprecipitation}

Cells were labeled with either the water-soluble biotin reagent sulfosuccinimidobiotin (sulfoNHS-biotin; Pierce Chemical Co., Rockford, IL, U.S.A.) or ${ }^{125} / \mathrm{I}$ lactoperoxidase using minor modifications of published methods. $(7,21)$ Briefly, for the nonradioactive procedure, adherent cells were rinsed free of culture medium with phosphate-buffered saline (PBS) and then labeled for $1 \mathrm{~h}$ at room temperature with the reagent at $0.2 \mathrm{mg} / \mathrm{ml}$ in $100 \mathrm{mM}$ HEPES, $\mathrm{pH} 8.0$. Following removal of the labeling solution, cells were lysed into buffer containing $10 \mathrm{mM}$ Tris, $\mathrm{pH} 7.2$, $150 \mathrm{mM} \mathrm{NaCl}, 1 \%$ sodium deoxycholate, $1 \%$ Triton X-100, $0.1 \%$ SDS, $0.025 \% \mathrm{NaN}_{3}, 5 \mathrm{mM}$ iodoacetamide, $1 \mathrm{mM} \mathrm{CaCl}_{2}, 1 \mathrm{mM} \mathrm{MgCl} 2,4 \mathrm{mM}$ phenylmethylsulfonyl fluoride (PMSF), and $0.25 \mathrm{TIU}$ of Aprotinin/ml. The lysate was pre-cleared with protein G-Sepharose (Pharmacia, Piscataway, NJ, U.S.A.) and immunoprecipitated with suitable antibodies. These comprised either LM609, a monoclonal which recognizes the complex $\alpha_{v} \beta_{3},(7)$ or a rabbit polyclonal antibody raised against the sequence of the human $\beta_{5}$ cytoplasmic tail.(22) The immune precipitates, recovered with excess protein G-Sepharose, washed prior to boiling with electrophoresis sample buffer, were subjected to SDS-PAGE in 6\% nonreducing minigels. The separated proteins were transferred to nitrocellulose (Nitro ME; MSI, Westboro, MA, U.S.A.) with a semidry blotter, using the manufacturer's instructions (BioRad, Richmond, CA, U.S.A.), and the blot was probed with $0.1 \%$ streptavidin-horseradish peroxidase (BoehringerMannheim, Indianapolis, IN, U.S.A.) in PBS, with color development with 4-chloronaphthol 
at $2 \mathrm{mg} / \mathrm{ml}$. In the studies using radioisotope, $150-\mathrm{mm}$ plates of adherent cells were labeled with $1 \mathrm{mCi}$ of ${ }^{125} \mathrm{I}$, using the lactoperoxidase method as described.(21) Rinsed plate contents were lysed with a minimal volume of buffer, following which equal numbers of trichloracetic acid-precipitable counts were immunoprecipitated, as described above, with either LM609, the monoclonal $\alpha_{v} \beta_{3}$-specific antibody, or a rabbit polyclonal raised against the amino acid sequence of the human $\beta_{3}$ cytoplasmic tail. (23) To detect all $\alpha_{\mathrm{v}}$-associated integrins on the cell surface, lysates from radiolabeled cells were immunoprecipitated with Chav, a murine monoclonal which recognizes the avian $\alpha_{v}$ subunit.(24,25) Analysis of all gels was performed by separation in nonreducing, $24 \mathrm{~cm} 6 \%$ SDS-PAGE gels, which were dried and exposed at $-70^{\circ} \mathrm{C}$ to Kodak X-Omat film (Eastman Kodak, Rochester, NY, U.S.A.), prior to development.

\section{Analysis of steady-state $\beta_{3}$ and $\beta_{5}$ mRNA levels}

Osteoclast precursors were treated for varying periods of time with vehicle or $10^{-5}$ to $10^{-8} \mathrm{M}$ all-trans retinoic acid without change of medium. At the relevant time, medium was removed, cells rinsed with PBS, and total RNA was isolated with RNAzol, according to the manufacturer's instructions (Teltest, Friendswood, TX, U.S.A.). Equal amounts of RNA were treated with formaldehyde and separated on $1 \%$ agarose gels, followed by transfer to a nylon membrane (Hybond-N; Amersham, Arlington Heights, IL, U.S.A.) using a vacuum blotter. Full-length cDNAs for the avian $\beta_{3}$ and $\beta_{5}$ gene products, both cloned in our laboratory,(7, 26) as well as a $2.2 \mathrm{~kb}$ fragment of the avian $\alpha_{\mathrm{v}}$ cDNA (27) were labeled by random priming and hybridized to filters overnight at $42^{\circ} \mathrm{C}$ in $5 \times$ SSPE, $5 \times$ Denhardt's solution, $50 \%$ formamide, $0.1 \%$ SDS, and $10 \%$ background quencher (Teltest). The filters were washed three times at $55^{\circ} \mathrm{C}$ with $1 \times \mathrm{SSPE}, 0.1 \% \mathrm{SDS}$, and exposed to film prior to development. In some experiments in which cells had been treated with retinoic acid, the membranes were stripped by boiling in $0.1 \%$ SDS in RNAse-free water, followed by washing in the same water. The membranes were then reprobed in the same manner with the avian $\alpha_{v}$ cDNA probe.

\section{Measurement of the rates of $\beta_{5}$ and $\beta_{3}$ mRNA synthesis}

Nuclear run-on assays were performed as follows. Nuclei were isolated from cells treated with either vehicle or $10^{-6} \mathrm{M}$ retinoic acid, using an established method.(21) Briefly, cells were lysed in $10 \mathrm{mM}$ Tris, pH 7.4, $10 \mathrm{mM} \mathrm{NaCl}, 3 \mathrm{mM} \mathrm{MgCl}_{2}$, and $0.5 \%$ Nonidet P-40. Nuclei were isolated by centrifugation at $400 \mathrm{rpm}$ and stored at $-80^{\circ} \mathrm{C}$ at a concentration of $10^{8}$ cells/ $\mathrm{ml}$ in $50 \mathrm{mM}$ HEPES, $\mathrm{pH} 8.0,5 \mathrm{mM} \mathrm{MgCl}_{2}, 0.5 \mathrm{mM}$ DTT, $1 \mathrm{mg} / \mathrm{ml}$ of bovine serum albumin, and $25 \%$ glycerol. To measure new RNA synthesis $\sim 5 \times 10^{7}$ nuclei were thawed and mixed with an equal volume of $2 \times$ reaction buffer (100 mM HEPES, pH 8.0, $4 \mathrm{mM} \mathrm{MgCl}_{2}, 6 \mathrm{mM}$ $\mathrm{MgOAc}, 4 \mathrm{mM}$ dithiothreitol, $2 \mathrm{mg} / \mathrm{ml}$ of bovine serum albumin, $300 \mathrm{mM} \mathrm{NH}_{4} \mathrm{Cl}, 1 \mathrm{mM}$ each ATP, CTP, and GTP, $20 \%$ glycerol, and $100 \mu \mathrm{Ci}$ of ${ }^{32} \mathrm{P}-\mathrm{UTP}(3000 \mathrm{Ci} / \mathrm{mmol}$; ICN, Costa Mesa, CA, U.S.A.). Incubation was carried out for 15 minutes at $37^{\circ} \mathrm{C}$, following which total RNA was extracted as described above. Equal amounts of trichloracetic acid-precipitable counts were slot hybridized to a nitrocellulose membrane (Biodot; BioRad), to which $10 \mu \mathrm{g}$ of linearized plasmid DNAs coding for avian $\beta_{3}$ and $\beta_{5}$ had been applied in $20 \times$ SSC. As controls, a cDNA coding for LEP, an avian lysosomal protein,(28) and plasmid DNA were applied in adjacent slots. The labeled RNA was hybridized at $55^{\circ} \mathrm{C}$ for $48 \mathrm{~h}$ in $5 \times \mathrm{SSC}, 50 \%$ formamide, $2 \times$ Denhardt's solution, $20 \mu \mathrm{g}$ of tRNA, $50 \mathrm{mM} \mathrm{NaH}_{2} \mathrm{PO}_{4}, 0,1 \%$ SDS, and $1 \times$ Background Quencher (Teltest). Membranes were subjected to three 5 -minute washes at $45^{\circ} \mathrm{C}$ with $2 \times \mathrm{SSC}$, $0.1 \%$ SDS for 5 minutes followed by three 15 -minute washes at $55^{\circ} \mathrm{C}$ with $0.2 \times \mathrm{SSC}, 0.1 \%$ SDS. Membranes were dried, exposed at $-70^{\circ} \mathrm{C}$ to Kodak Scientific Imaging film which was developed after appropriate times. 


\section{RESULTS}

\section{Freshly isolated avian osteoclast precursors express a novel $\alpha_{v}$ integrin, but not $\alpha_{v} \beta_{3}$}

We find that mature avian osteoclasts express the integrin $\alpha_{v} \beta_{3}$, and this heterodimer plays an important role in their bone-resorptive capacity.(29) Having characterized the integrins on mature avian osteoclasts,(29) we turned to the $\alpha_{\mathrm{v}}$-bearing integrins present on their precursors, which, to develop the osteoclast phenotype, must bind to bone. As seen in Fig. 1, osteoclast precursors analyzed with both the $\alpha_{\mathrm{v}} \beta_{3}$-specific antibody LM609 and Chav, a monoclonal antibody (MAb) to the avian $\alpha_{\mathrm{v}}$ chain, express on their surface, a novel integrin, but not $\alpha_{v} \beta_{3}$. Of note, $1,25(\mathrm{OH})_{2} \mathrm{D}_{3}$ fails to alter expression of the novel integrin while having the expected effect $(7,8)$ of increasing $\alpha_{v} \beta_{3}$.

\section{The novel integrin on avian osteoclast precursors is $\alpha_{\mathrm{v}} \beta_{5}$}

Based on the known association of $\alpha_{v}$ with $\beta_{5}$ in human monocytes,(19) and the fact that, like $\alpha_{\mathrm{v}} \beta_{3}, \alpha_{\mathrm{v}} \beta_{5}$ recognizes the RGD motif in several bone matrix proteins,(18) we postulated the unknown subunit associating with $\alpha_{\mathrm{v}}$ is the avian $\beta_{5}$ homolog. The likelihood that this is so was supported by the finding that, using homology polymerase chain reaction, we obtained from the precursor cells, a cDNA highly homologous to that of human $\beta_{5}$. (26) In particular, comparison of the amino acid sequence at the carboxyl terminus with that of human $\beta_{5}$ (22) demonstrates almost complete identity (Fig. 2). Given this fact, we used a polyclonal antibody raised against the sequence of the human $\beta_{5}$ cytoplasmic tail to ask if the novel integrin is $\alpha_{\mathrm{v}} \beta_{5}$.

Osteoclast precursors treated with vehicle or $10^{-8} \mathrm{M} 1,25(\mathrm{OH})_{2} \mathrm{D}_{3}$ were surface labeled with ${ }^{125} \mathrm{I}$, and the lysate was immunoprecipitated with either of two polyclonal antibodies, one of which is $\beta_{5}$-specific and the second, raised against the sequence of the human $\beta_{3}$ cytoplasmic tail. To confirm the complex precipitated by this latter polyclonal antibody is, in fact $\alpha_{\mathrm{v}} \beta_{3}$, a portion of lysate was precipitated with the integrin-specific antibody LM609. To detect all $\alpha_{\mathrm{v}}$-associated integrins on the cell surface, a final sample was precipitated with Chav mAb.

Given $1,25(\mathrm{OH}) 2 \mathrm{D}_{3}$ stimulates expression of $\alpha_{\mathrm{v}} \beta_{3}$, (7) we anticipated this integrin would be present on cells exposed to the steroid. This expectation was confirmed by precipitation with both LM609 and the polyclonal anti- $\beta_{3}$ cytoplasmic tail antibody (Fig. 3). Likewise, use of the $\beta_{5}$-specific antibody results in only two bands, one migrating at $160 \mathrm{kDa}$, representing the $\alpha_{\mathrm{v}}$ subunit and the other at $80 \mathrm{kDa}$, confirming the novel integrin is $\alpha_{\mathrm{v}} \beta_{5}$. In contrast, when Chav, capable of immunoprecipitating all $\beta$ chains bound to $\alpha_{\mathrm{v}}$, was the precipitating antibody, a complex of three bands, representing both $\alpha_{\mathrm{v}} \beta_{3}$ and $\alpha_{\mathrm{v}} \beta_{5}$, is obtained.

\section{Retinoic acid decreases surface expression of $\alpha_{\mathrm{v}} \beta_{5}$ by avian osteoclast precursors}

$1,25(\mathrm{OH})_{2} \mathrm{D}_{3}$ fails to alter surface expression, by osteoclast precursors, of $\alpha_{\mathrm{v}} \beta_{5}$ (Fig. 1). Since both this steroid and retinoic acid increase $\alpha_{v} \beta_{3}$ expression, (21) we asked if the retinoid modulates $\alpha_{\mathrm{v}} \beta_{5}$. As seen in Fig. 4A, which details expression of $\alpha_{\mathrm{v}}$ integrins by adherent osteoclast precursors treated with $10^{-6} \mathrm{M}$ retinoic acid, the retinoid, decreases $\alpha_{\mathrm{v}} \beta_{5}$ while increasing $\alpha_{\mathrm{v}} \beta_{3}$. To determine if retinoic acid inhibition of $\alpha_{\mathrm{v}} \beta_{5}$ expression is dose dependent, cells were surface labeled with a biotin derivative, a technique we previously validated for quantitating $\alpha_{v}$ integrins. (21) This approach enabled us to study more variables than reasonable using iodination. As seen in Fig. 4B, $\alpha_{v} \beta_{5}$ expression is progressively decreased by increasing amounts of retinoic acid. The effect is detectable at concentrations of retinoid as low as $10^{-8}$ $\mathrm{M}$, which is within the physiological range.(30)

Retinoic acid treatment of avian osteoclast precursors decreases steady-state $\beta_{5}$ mRNA in a time- and dose-dependent manner, but fails to alter $\alpha_{v}$ mRNA levels. 
Retinoic acid-augmented surface expression of $\alpha_{v} \beta_{3}$ involves increased steady-state $\beta_{3}$ integrin subunit mRNA.(21) To test if an analogous situation exists for $\alpha_{v} \beta_{5}$, we performed Northern analysis, with time, of cells treated with various concentrations of retinoic acid. The results of this experiment, shown in Fig. 5, demonstrate a dose-dependent decrease in steady-state mRNA under the $\beta_{5}$ influence of the steroid with induction occurring within the physiological range. $\beta_{5}$ mRNA, in untreated cells, is present at isolation, peaks at day 3 and returns to basal levels by day 5 (Fig. 5). Alternatively, 1 day of retinoic acid treatment blunts $\beta_{5}$ mRNA expression. Northern analysis using a full-length avian cDNA reveals concentrations of retinoic acid as high as $10^{-6} \mathrm{M}$ fail to alter $\alpha_{\mathrm{v}}$ mRNA levels (data not shown).

\section{Retinoic acid fails to alter the rate of transcription of the avian $\beta_{5}$ gene}

To determine whether retinoic acid-mediated decrease in $\beta_{5}$ mRNA arises from inhibited gene transcription, we performed run-on studies, using nuclei from cells treated with either vehicle or $10^{-6} \mathrm{M}$ steroid. Retinoic acid, while transactivating the $\beta_{3}$ gene as reported, fails to alter $\beta_{5}$ transcription (Fig. 6). In these studies, transcription of LEP acts as a negative control.

\section{DISCUSSION}

Our results indicate the integrin $\alpha_{\mathrm{v}} \beta_{3}$, a critical mediator of osteoclast-bone interactions, is not expressed on early avian osteoclast precursors. However, precursor proliferation, maturation, and fusion, events central to osteoclastogenesis, require the cells to attach to the RGD-rich bone matrix. Thus, we asked whether another $\alpha_{\mathrm{v}}$ integrin is present on early precursors lacking $\alpha_{\mathrm{v}} \beta_{3}$. Using a MAb recognizing the avian $\alpha_{\mathrm{v}}$ subunit, we established the presence, on these early cells, of an integrin whose $\beta$ chain is smaller than that of avian $\beta_{1}$ or $\beta_{3}$, namely $105 \mathrm{kDa}$ and $95 \mathrm{kDa}$, respectively. $(21,31)$ These observations, plus the fact that neither an $\alpha_{\mathrm{v}} \beta_{3}$-specific antibody, LM609, nor CSAT, an antibody targeting the avian $\beta_{1}$ chain, recognize the $80 \mathrm{kDa}-$ associated heterodimer (data not shown), suggest avian osteoclast precursors, express an $\alpha_{\mathrm{v}}$ integrin which is neither $\alpha_{\mathrm{v}} \beta_{1}$ or $\alpha_{\mathrm{v}} \beta_{3}$.

Given exclusion of $\alpha_{\mathrm{v}} \beta_{1}$ and $\alpha_{\mathrm{v}} \beta_{3}$, the remaining likely possibilities remained $\alpha_{\mathrm{v}} \beta_{5}, \alpha_{\mathrm{v}} \beta_{6}$, or $\alpha_{v} \beta_{8}$. While neither of the latter two integrins are known to be expressed by macrophages, $\alpha_{v} \beta_{5}$ is found on cells of monocyte lineage. $(19,32)$ We confirmed the presence of this heterodimer on early osteoclast precursors by immunoprecipitation using an antibody prepared against the human $\beta_{5}$ cytoplasmic tail sequence.

Having documented $\alpha_{\mathrm{v}} \beta_{5}$ on osteoclast precursors, we turned to its regulation. We find that, unlike the case of $\alpha_{\mathrm{v}} \beta_{3}, 1,25(\mathrm{OH})_{2} \mathrm{D}_{3}$ fails to alter expression of $\alpha_{\mathrm{v}} \beta_{5}$. In contrast, treatment of precursors cells with retinoic acid, a related osteoclastogenic steroid, prompts a time- and dose-dependent decrease in the integrin. Furthermore, as demonstrated previously,(21) in contrast to $\beta_{3}$ mRNA, which is enhanced by retinoic acid, a maximal concentration of the steroid fails to alter the $\alpha_{\mathrm{v}}$ message, which is abundant in both treated and control cells.

Although exposure of cells to retinoic acid leads to diminished $\beta_{5}$ steady-state mRNA, nuclear run-on studies indicate that the rate of transcription of the $\beta_{5}$ gene is unaltered. This observation suggests that retinoic acid treatment results in destabilization of $\beta_{5}$ mRNA. However, using the standard approach of measuring mRNA half-life with the transcriptional inhibitor actinomycin $\mathrm{D}$, we were unable to confirm this hypothesis (data not shown). While the mechanism(s) by which retinoic acid decreases $\beta_{5}$ mRNA remain to be elucidated, the possibility exists that treatment with the retinoid leads to a block in transcriptional elongation. A similar finding was reported with respect to c-myc in the human promyelocytic cell line HL-60 following exposure to retinoic acid. $(33,34)$ In these earlier studies, when nuclear runon analysis was performed, retinoic acid-treated cells, using as probes cDNA sequences coding for two separate exons, there was no change in the rate of transcription of the more $5^{\prime}$ exon, 
while that of its more $3^{\prime}$ counterpart decreased significantly. The avian $\beta_{5}$ gene has not been cloned and so we are not in a position to carry out analogous studies.

Overall, our results suggest that $\alpha_{\mathrm{v}} \beta_{3}$ and $\alpha_{\mathrm{v}} \beta_{5}$, while both capable of recognizing a similar range of ligands, play separate roles during avian osteoclastogenesis, a hypothesis consistent with observations that the integrins are functionally discrete. Thus, in human foreskin fibroblasts, $\alpha_{\mathrm{v}} \beta_{5}$, but not $\alpha_{\mathrm{v}} \beta_{3}$, mediates uptake of vitronectin, a ligand for both integrins. (35) Likewise, in cells expressing $\alpha_{v} \beta_{3}$ or $\alpha_{v} \beta_{5}$, it is the latter integrin, and not the former, which facilitates entry of the human adenovirus type 2.(36) An analogous finding obtains for $\alpha_{v} \beta_{5}$ and not $\alpha_{v} \beta_{3}$, with respect to uptake of asbestos fibers by mesothelial cells.(37) Finally, in human smooth muscle cells expressing both $\alpha_{\mathrm{v}} \beta_{3}$ and $\alpha_{\mathrm{v}} \beta_{5}$, both attachment to and migration on the RGD-containing protein osteopontin are $\alpha_{v} \beta_{3}$ - and not $\alpha_{v} \beta_{5}$-dependent.(38)

The finding that retinoic acid suppresses $\alpha_{\mathrm{v}} \beta_{5}$ expression, coupled with our earlier reports on $\alpha_{v} \beta_{3}$ induction by both $1,25(\mathrm{OH})_{2} \mathrm{D}_{3}$ and retinoic acid, suggests a model for the role of these two $\alpha_{\mathrm{v}}$ integrins during osteoclast differentiation. Given that early osteoclast precursors capable of matrix recognition express the $\beta_{5}$ and not the $\beta_{3}$-associated heterodimer, the cells likely utilize $\alpha_{\mathrm{v}} \beta_{5}$ for initial attachment to bone. As the cells differentiate under the influence of $1,25(\mathrm{OH})_{2} \mathrm{D}_{3}$ and retinoic acid, levels of $\alpha_{\mathrm{v}} \beta_{5}$ fall, while those of $\alpha_{\mathrm{v}} \beta_{3}$ rise, leading to a situation where this latter integrin is the dominant RGD-recognizing moiety on mature osteoclasts, a result seen in both human(39) and rodent(40) cells.

Retinoic acid directly stimulates osteoclastogenesis and increases production, by mature osteoclasts, of the RGD-containing bone matrix protein osteopontin.(41) Thus, our findings that the retinoid reciprocally alters expression of two $\alpha_{\mathrm{v}}$ integrins, whose roles are probably complementary, provide yet another molecular marker for the skeletal actions of this steroid.

\section{Acknowledgments}

This work was supported in part by National Institutes of Health grants AR42404 (F.P.R.) AR32788, and DE05413 and a grant from the Shriners Hospital, St. Louis Unit (S.L.T.).

\section{References}

1. Suda T, Takahashi N, Martin TJ. Modulation of osteoclast differentiation. Endocr Rev 1992;13:6680. [PubMed: 1555533]

2. Teitelbaum, SL.; Tondravi, MM.; Ross, FP. Osteoporosis. In: Marcus, R.; Feldman, D.; Kelsey, J., editors. Osteoclast Biology. Vol. 3. Academic Press; San Diego, CA, U.S.A: 1996. p. 61-94.

3. O'Neill RP, Jones SJ, Boyde A, Taylor ML, Arnett TR. Effect of retinoic acid on the resorptive activity of chick osteoclasts in vitro. Bone 1992;13:23-27. [PubMed: 1581105]

4. Scheven BA, Hamilton NJ. Retinoic acid and 1,25-dihydroxyvitamin $\mathrm{D}_{3}$ stimulate osteoclast formation by different mechanisms. Bone 1990;11:53-59. [PubMed: 2331432]

5. Alvarez JI, Teitelbaum SL, Blair HC, Greenfield EM, Athanasou NA, Ross FP. Generation of avian cells resembling osteoclasts from mononuclear phagocytes. Endocrinology 1991;128:2324-2335. [PubMed: 1850350]

6. Cao X, Ross FP, Zhang L, MacDonald PN, Chappel J, Teitelbaum SL. Cloning of the promoter for the avian integrin $\beta_{3}$ subunit gene and its regulation by 1,25 -dihydroxyvitamin $\mathrm{D}_{3}$. J Biol Chem 1993;268:27371-27380. [PubMed: 8262978]

7. Mimura H, Cao X, Ross FP, Chiba M, Teitelbaum SL. 1,25-dihydroxyvitamin $\mathrm{D}_{3}$ transcriptionally activates the $\beta_{3}$-integrin subunit gene in avian osteoclast precursors. Endocrinology 1994;134:10611066. [PubMed: 8119143]

8. Medhora MM, Teitelbaum SL, Chappel J, Alvarez J, Mimura H, Ross FP, Hruska K. 1 $\alpha, 25-$ dihydroxyvitamin $\mathrm{D}_{3}$ up-regulates expression of the osteoclast integrin $\alpha_{\mathrm{v}} \beta_{3}$. J Biol Chem 1993;268:1456-1461. [PubMed: 7678259] 
9. Clohisy DR, Bar-Shavit Z, Chappel J, Teitelbaum SL. 1,25-dihydroxyvitamin $\mathrm{D}_{3}$ modulates bone marrow macrophage precursor proliferation and differentiation: Upregulation of the mannose receptor. J Biol Chem 1987;262:15922-15929. [PubMed: 3680233]

10. Wahli W, Martinez E. Superfamily of steroid nuclear receptors: Positive and negative regulators of gene expression. FASEB J 1991;5:2243-2249. [PubMed: 1860615]

11. Hough S, Avioli LV, Muir H, Gelderblom D, Jenkins G, Kurasi H, Slatopolsky E, Bergfeld MA, Teitelbaum SL. Effects of hypervitaminosis A on the bone and mineral metabolism of the rat. Endocrinology 1988;122:2933-2939. [PubMed: 3371268]

12. Oreffo RO, Teti A, Triffitt JT, Francis MJ, Carano A, Zallone AZ. Effect of vitamin D on bone resorption: Evidence for direct stimulation of isolated chicken osteoclasts by retinol and retinoic acid. J Bone Miner Res 1988;3:203-210. [PubMed: 3063069]

13. Togari A, Kondo M, Arai M, Matsumoto S. Effects of retinoic acid on bone formation and resorption in cultured mouse calvaria. Gen Pharmacol 1991;22:287-292. [PubMed: 2055423]

14. Le Douarin B, vom Baur E, Zechel C, Heery D, Heine M, Vivat V, Gronemeyer H, Losson R, Chambon P. Ligand-dependent interaction of nuclear receptors with potential transcriptional intermediary factors (mediators). Philos Trans R Soc Lond B Biol Sci 1996;351:569-578. [PubMed: 8735280]

15. Haussler MR, Jurutka PW, Hsieh JC, Thompson PD, Selznick SH, Haussler CA, Whitfield GK. New understanding of the molecular mechanism of receptor-mediated genomic actions of the vitamin D hormone. Bone 1995;17:33S-38S. [PubMed: 8579895]

16. Pereira FA, Qiu Y, Tsai MJ, Tsai SY. Chicken ovalbumin upstream promoter transcription factor (COUP-TF): Expression during mouse embryogenesis. J Steroid Biochem Mol Biol 1995;53:503508. [PubMed: 7626501]

17. Hynes RO. Integrins: Versatility, modulation, and signaling in cell adhesion. Cell 1992;69:11-25. [PubMed: 1555235]

18. Hu DD, Lin EC, Kovach NL, Hoyer JR, Smith JW. A biochemical characterization of the binding of osteopontin to integrins $\alpha_{\mathrm{v}} \beta_{1}$ and $\alpha_{\mathrm{v}} \beta_{5}$. J Biol Chem 1995;270:26232-26238. [PubMed: 7592829]

19. De Nichilo MO, Burns GF. Granulocyte-macrophage and macrophage colony-stimulating factors differentially regulate $\alpha_{\mathrm{V}}$ integrin expression on cultured human macrophages. Proc Natl Acad Sci USA 1993;90:2517-2521. [PubMed: 7681600]

20. De Nichilo MO, Yamada KM. Integrin $\alpha_{\mathrm{V}} \beta_{5}$-dependent serine phosphorylation of paxillin in cultured human macrophages adherent to vitronectin. J Biol Chem 1996;271:11016-11022. [PubMed: 8631923]

21. Chiba M, Teitelbaum SL, Cao X, Ross FP. Retinoic acid stimulates expression of the functional osteoclast integrin $\alpha_{\mathrm{V}} \beta_{3}$ : Transcriptional activation of the $\beta_{3}$ but not $\alpha_{\mathrm{V}}$ gene. J Cell Biochem 1996;62:467-475. [PubMed: 8891892]

22. Ramaswamy H, Hemler ME. Cloning, primary structure and properties of a novel human integrin beta subunit. EMBO J 1990;9:1561-1568. [PubMed: 2328726]

23. Fitzgerald LA, Steiner B, Rall SC Jr, Lo SS, Phillips DR. Protein sequence of endothelial glycoprotein IIIa derived from a cDNA clone: Identity with platelet glycoprotein IIIa and similarity to 'integrin'. J Biol Chem 1987;262:3936-3939. [PubMed: 3494014]

24. Neugebauer KM, Venstrom KA, Reichardt LF. Adhesion of a chicken myeloblast cell line to fibrinogen and vitronectin through a $\beta_{1}$-class integrin. J Cell Biol 1992;116:809-815. [PubMed: 1370500]

25. Neugebauer KM, Reichardt LF. Cell-surface regulation of $\beta_{1}$-integrin activity on developing retinal neurons. Nature 1991;350:68-71. [PubMed: 1706071]

26. Martin J, Teitelbaum SL, Ross FP, Zhang L, Cao X. Cloning and regulation of integrins on ostoclast precursors. J Bone Miner Res 1994;9:S133.

27. Bossy B, Reichardt LF. Chick integrin $\alpha_{\mathrm{v}}$ subunit molecular analysis reveals high conservation of structural domains and association with multiple $\beta$ subunits in embryo fibroblasts. Biochemistry 1990;29:10191-10198. [PubMed: 1703004]

28. Fambrough DM, Takeyasu K, Lippincott-Schwarz J, Siegel NR. Structure of LEP100, a glycoprotein that shuttles between lysosomes and the plasma membrane, deduced from the nucleotide sequence of the encoding cDNA. J Cell Biol 1988;106:61-67. [PubMed: 3339090] 
29. Ross FP, Alvarez JI, Chappel J, Sander D, Butler WT, Farach-Carson MC, Mintz KA, Robey PG, Teitelbaum SL, Cheresh DA. Interactions between the bone matrix proteins osteopontin and bone sialoprotein and the osetoclast integrin $\alpha_{\mathrm{v}} \beta_{3}$ potentiate bone resorption. J Biol Chem 1993;268:99019907. [PubMed: 8486670]

30. Eckhoff C, Nau H. Identification and quantitation of all-trans- and 13-cis-retinoic acid and 13-cis-4oxoretinoic acid in human plasma. J Lipid Res 1990;31:1445-1454. [PubMed: 2280185]

31. Tamkun JW, DeSimone DW, Fonda D, Patel RS, Buck C, Horwitz AF, Hynes RO. Structure of integrin, a glycoprotein involved in the transmembrane linkage between fibronectin and actin. Cell 1986;46:271-282. [PubMed: 3487386]

32. Inoue M, Teitelbaum SL, Ross FP. Granulocyte-macrophage colony stimulating factor reciprocally regulates $\alpha_{\mathrm{V}}$-associated integrins on murine osteoclast precursors. Mol Endocrinol. 1998(in press)

33. Bentley DL, Groudine M. A block to elongation is largely responsible for decreased transcription of c-myc in differentiated HL60 cells. Nature 1986;321:702-706. [PubMed: 3520340]

34. Bentley DL, Groudine M. Sequence requirementf for premature termination of transcription in the human c-myc gene. Cell 1988;53:245-256. [PubMed: 2834065]

35. Panetti TS, McKeown-Longo PJ. The $\alpha_{\mathrm{v}} \beta_{5}$ integrin receptor regulates receptor-mediated endocytosis of vitronectin. J Biol Chem 1993;268:11492-11495. [PubMed: 7685013]

36. Wickham TJ, Filardo EJ, Cheresh DA, Nemerow GR. Integrin $\alpha_{\mathrm{v}} \beta_{5}$ selectively promotes adenovirus mediated cell membrane permeabilization. J Cell Biol 1994;127:257-264. [PubMed: 7523420]

37. Boylan AM, Sanan DA, Sheppard D, Broaddus VC. Vitronectin enhances internalization of crocidolite asbestos by rabbit pleural mesothelial cells via the integrin $\alpha_{\mathrm{v}} \beta_{5}$. J Clin Invest 1995;96:1987-2001. [PubMed: 7560092]

38. Liaw L, Skinner MP, Raines EW, Ross R, Cheresh DA, Schwartz SM, Giachelli CM. The adhesive and migratory effects of ostepontin are mediated via distinct cell surface integrins: Role of $\alpha_{\mathrm{v}} \beta_{5}$ in smooth muscle cell migration to osteopontin in vitro. J Clin Invest 1995;95:713-724. [PubMed: 7532190]

39. Nesbitt S, Nesbit A, Helfrich M, Horton M. Biochemical characterization of human osteoclast integrins: Osteoclasts express $\alpha_{\mathrm{v}} \beta_{5}, \alpha_{2} \beta_{1}$, and $\alpha_{\mathrm{v}} \beta_{1}$ integrins. J Cell Biol 1993;268:16737-16745.

40. Shinar DM, Schmidt A, Halperin D, Rodan GA, Weinreb M. Expression of $\alpha_{\mathrm{V}}$ and $\beta_{5}$ integrin subunits in rat osteoclasts in situ. J Bone Miner Res 1993;8:403-414. [PubMed: 8475790]

41. Kaji H, Sugimoto T, Kanatani M, Fukase M, Kumegawa M, Chihara K. Retinoic acid induces osteoclast-like cell formation by directly acting on hemopoietic blast cells and stimulates ostepontin mRNA expression in isolated osteoclasts. Life Sci 1995;56:1903-1913. [PubMed: 7746099] 


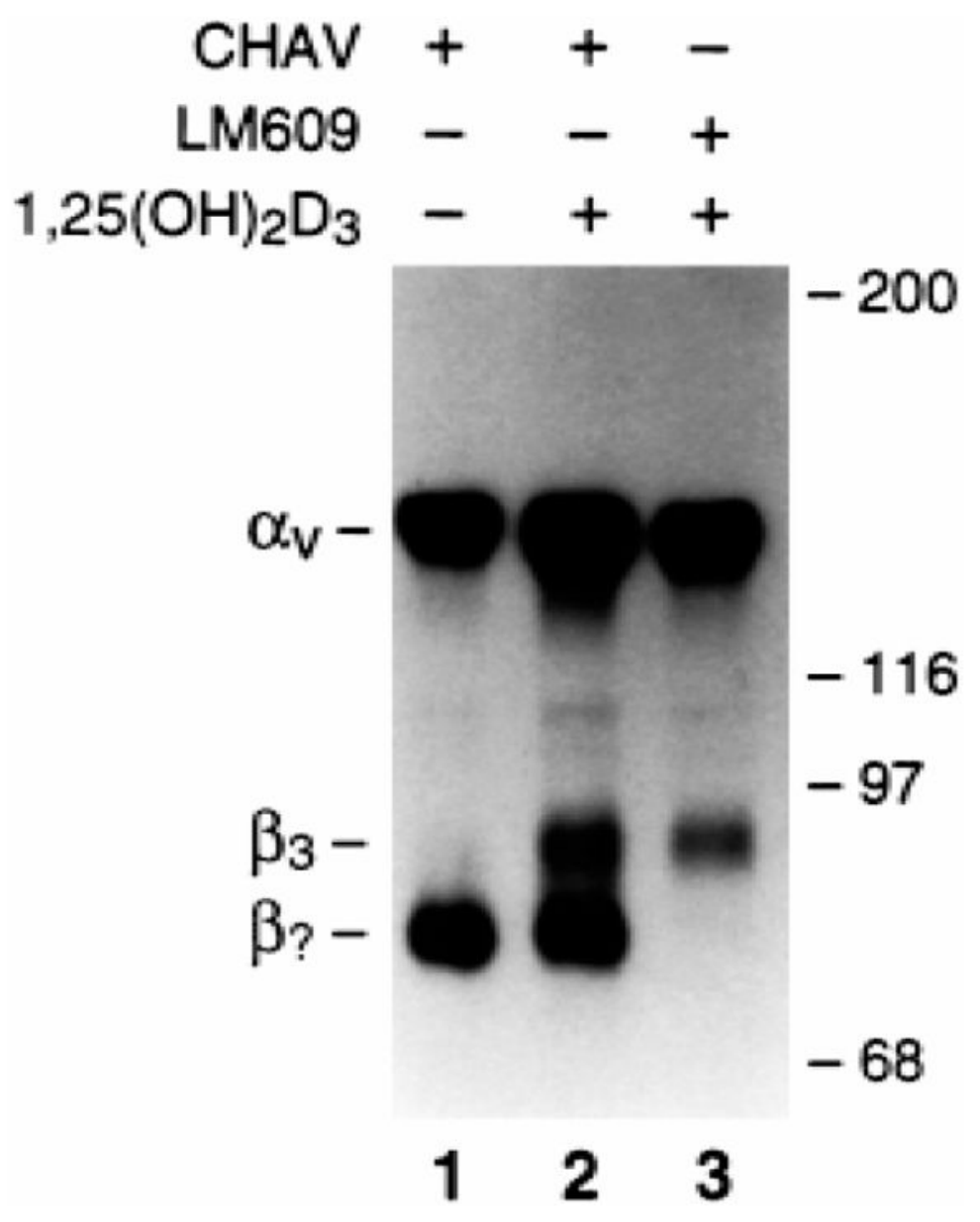

FIG. 1.

Avian osteoclast precursors express a novel $\alpha_{\mathrm{v}}$ integrin. Freshly isolated precursor cells from the marrow of hens fed a calcium-deficient diet were grown in the absence (lane 1) or presence (lanes 2 and 3) of $10^{-8} \mathrm{M} 1,25(\mathrm{OH})_{2} \mathrm{D}_{3}$. The expression of $\alpha_{\mathrm{v}}$ integrins was determined by ${ }^{125}$ I surface labeling followed by immunoprecipitation of lysates with LM609, an antibody specific for the $\alpha_{\mathrm{v}} \beta_{3}$ complex, or Chav, a MAb recognizing all avian $\alpha_{\mathrm{v}}$ integrins. The integrin $\alpha_{\mathrm{v}} \beta_{3}$, while absent in untreated cells (lane 1), is induced by $1,25(\mathrm{OH})_{2} \mathrm{D}_{3}$ (lane 2). Untreated cells contains another $\alpha_{\mathrm{v}}$ integrin whose levels are not altered by $1,25(\mathrm{OH})_{2} \mathrm{D}_{3}$ (lane 2 ). The size of the novel $\beta$ chain ( $\beta$ ?) is $80 \mathrm{kDa}$, smaller than that reported for members of this family of integrin subunits. 


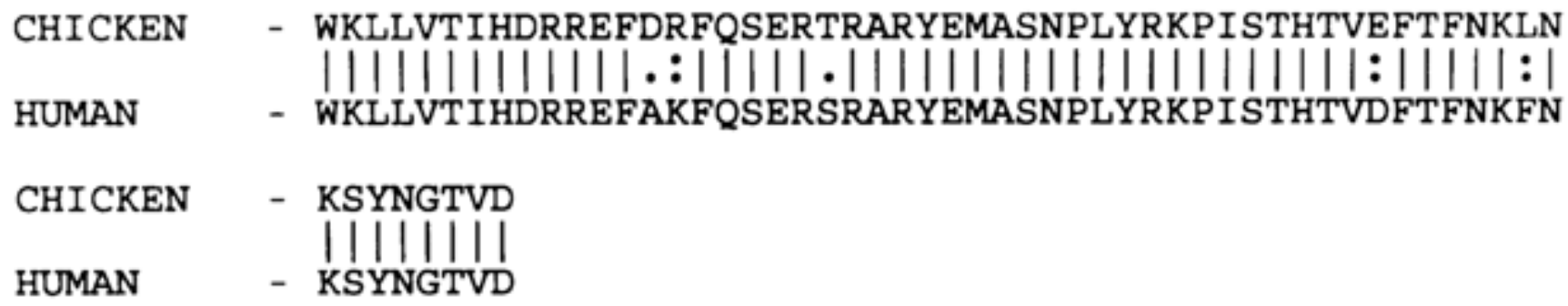

FIG. 2.

The amino acid sequence of the avian and human $\beta_{5}$ cytoplasmic tails are homologous. A cDNA coding for the mature avian $\beta_{5}$ protein was obtained by a combination of homology polymerase chain reaction and library screening. Translation of this cDNA provided the amino acid sequence of the protein, whose cytoplasmic tail (upper line) is compared with human $\beta_{5}$ (lower line). The sequences are $96 \%$ similar and $92 \%$ identical. 


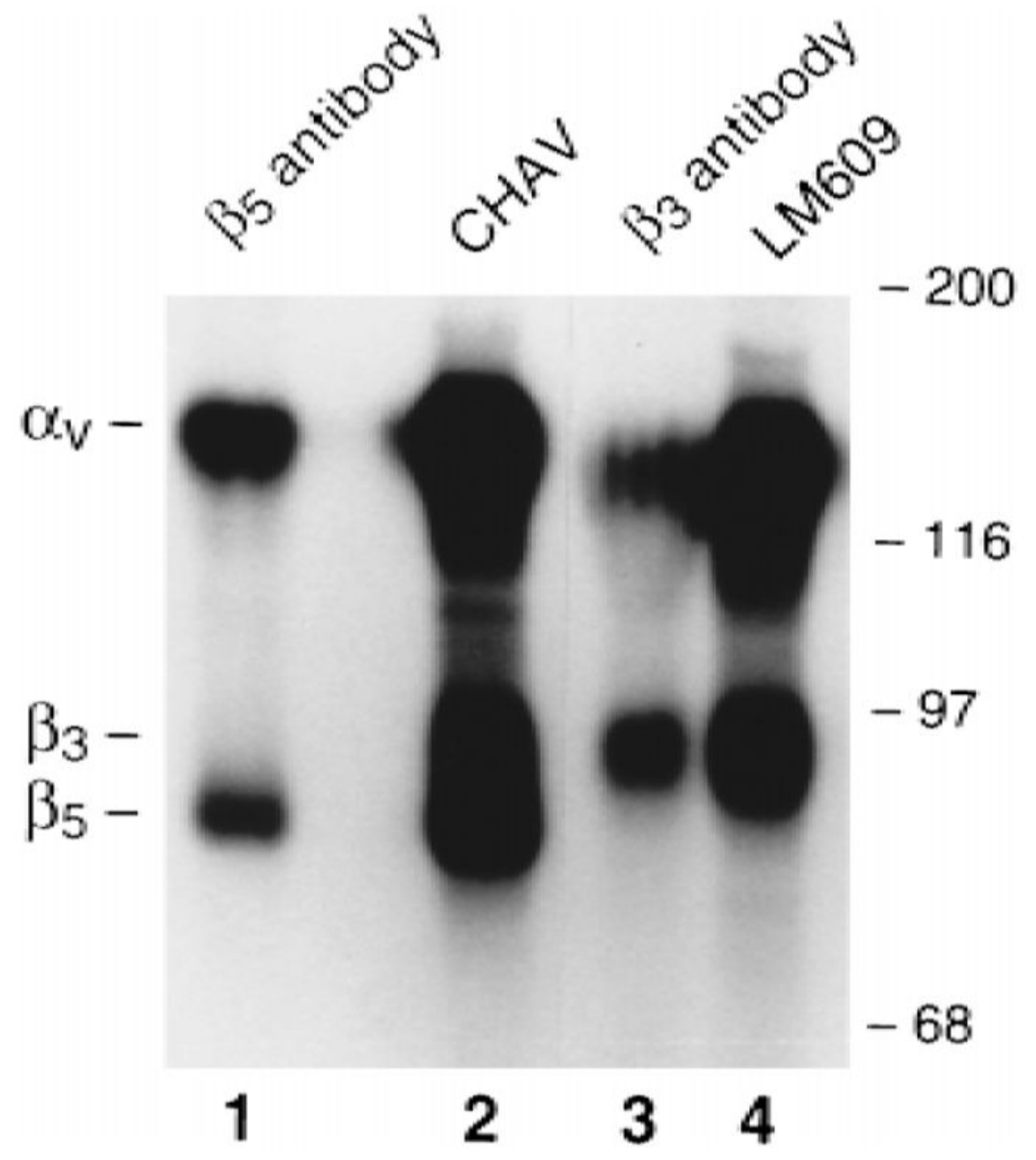

FIG. 3.

The integrin present on freshly isolated avian osteoclast precursors is $\alpha_{\mathrm{v}} \beta_{5}$. Cells, isolated and treated with vehicle (lane 1) or $10^{-8} \mathrm{M} 1,25(\mathrm{OH})_{2} \mathrm{D}_{3}$ (lanes 2-4), were surface labeled and immunoprecipitated with the following antibodies: a rabbit polyclonal antibody generated against the human $\beta_{5}$ cytoplasmic tail (lane 1); Chav, a MAb recognizing all avian $\alpha_{v}$ integrins (lane 2); a rabbit polyclonal antibody generated against the human $\beta_{3}$ cytoplasmic tail (lane 3); and LM609, a MAb specific for the $\alpha_{v} \beta_{3}$ heterodimer (lane 4). Steroid-treated cells express both $\alpha_{v} \beta_{3}$ and a heterodimer recognized by the $\beta_{5}$ tail antibody, while those cultured without $1,25(\mathrm{OH})_{2} \mathrm{D}_{3} \alpha_{\mathrm{v}} \beta_{5}$ have only on their surface. 


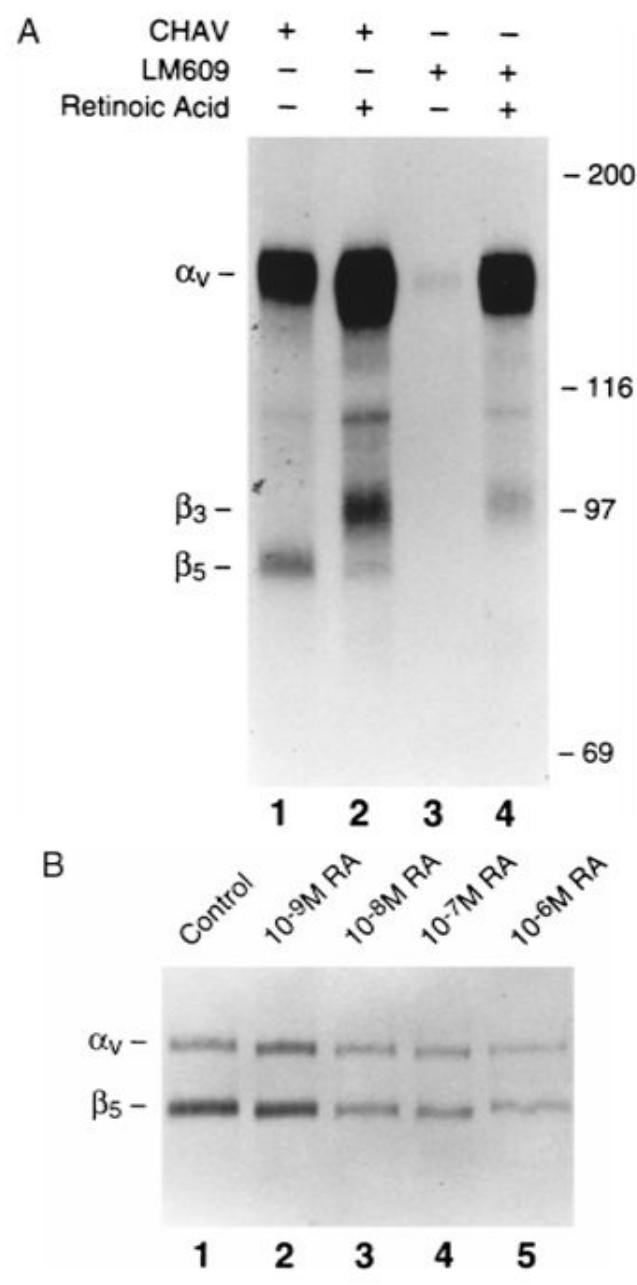

FIG. 4.

(A) Retinoic acid reciprocally regulates $\alpha_{\mathrm{v}} \beta_{3}$ and $\alpha_{\mathrm{v}} \beta_{5}$ expression on avian osteoclast precursors. Cells were isolated from marrow and treated for 3 days with vehicle (lanes 1 and 3) or 10-6 M retinoic acid (lane 2 and 4). Integrin expression was determined on ${ }^{125}$ I surfacelabeled cells using the antibodies Chav (all $\alpha_{\mathrm{v}}$ integrins) and LM609 ( $\alpha_{\mathrm{v}} \beta_{3}$ only). Retinoic acid, while stimulating $\alpha_{\mathrm{v}} \beta_{3}$ expression (compare lanes 3 and 4), decreases that of $\alpha_{\mathrm{v}} \beta_{5}$ (compare lanes 1 and 2). (B) The effect of retinoic acid on $\alpha_{\mathrm{v}} \beta_{5}$ expression is dose dependent. Cells treated for 3 days with varying amounts of retinoic acid were surface labeled with sulfobiotin and immunoprecipitated with the $\beta_{5}$-specific antibody. 

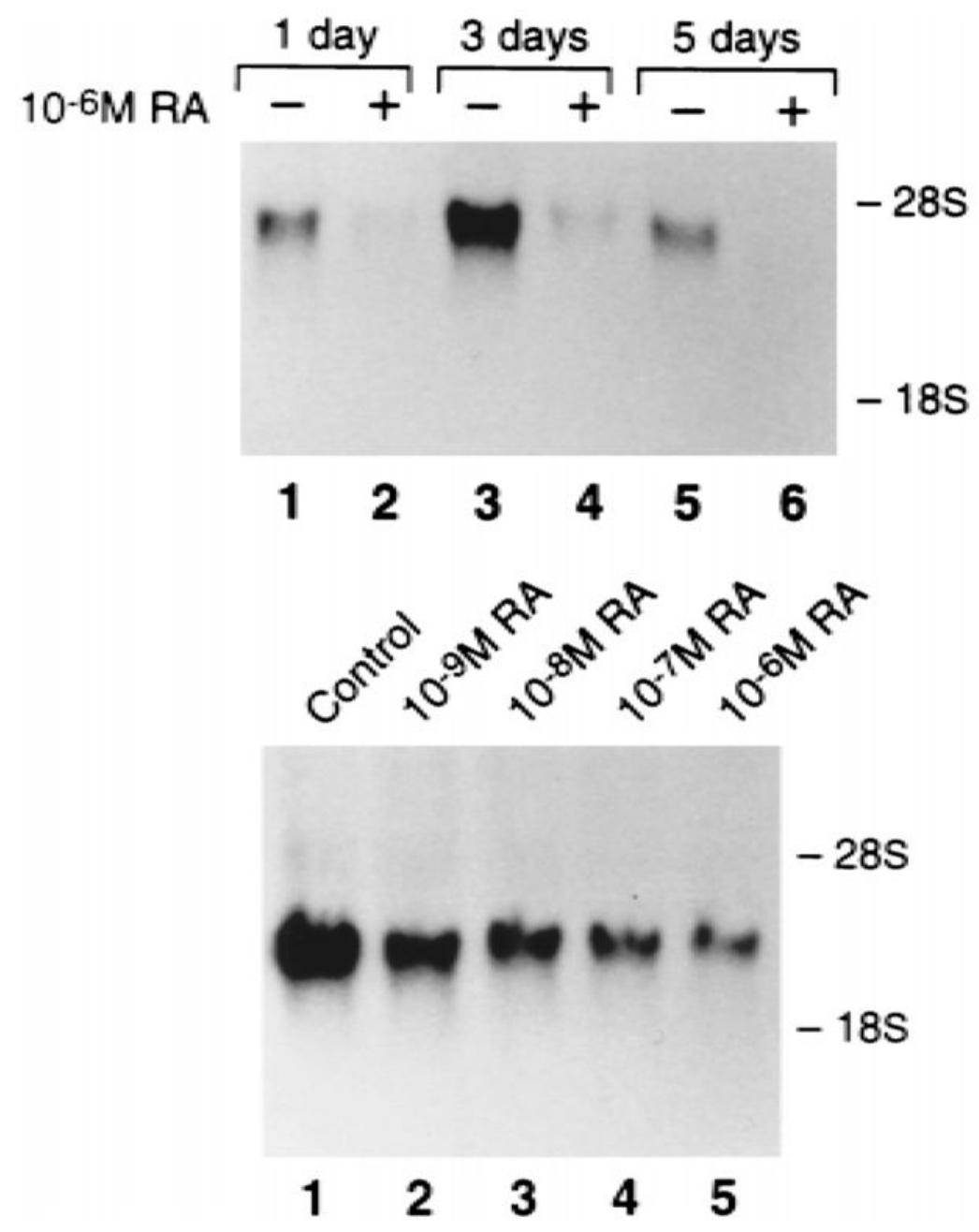

FIG. 5.

Retinoic acid alters $\alpha_{\mathrm{v}} \beta_{5}$ expression by decreasing $\beta_{5}$ steady-state mRNA levels, in a time- and dose-dependent manner. Cells were treated with vehicle or $10^{-6} \mathrm{M}$ retinoic acid for up to 5 days (top panel) or for 3 days with vehicle (control) or varying amounts of retinoic acid (lower panel), at which time Northern analysis was performed. 


\section{C}

$\mathbf{R}$

$\boldsymbol{\beta}_{5}$

$\boldsymbol{\beta}_{3}$

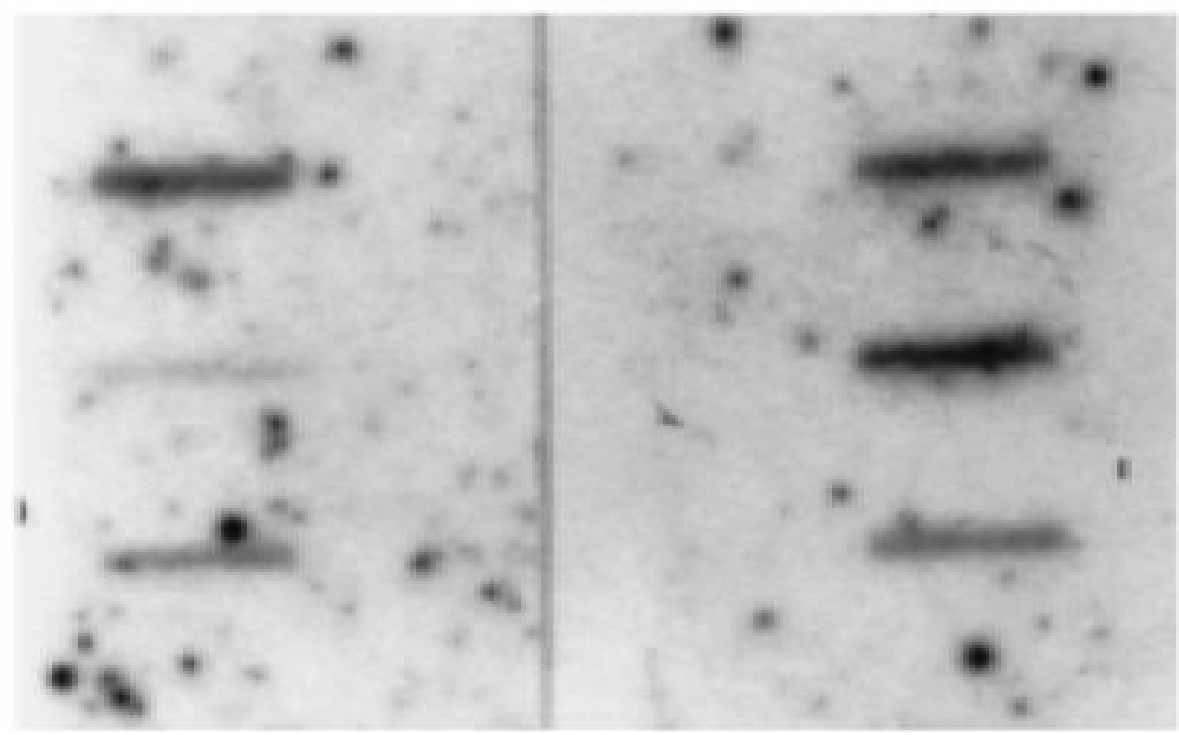

FIG. 6.

Retinoic acid accelerates $\beta_{3}$ but not $\beta_{5}$ transcription. Nuclei isolated from cells treated with vehicle or $10^{-6} \mathrm{M}$ retinoic acid were used in run-on studies, using excess $\beta_{3}, \beta_{5}$, and LEP (negative control) cDNA probes. C 4 control cells, R 4 retinoic acid-treated cells. 